\title{
Glucose partitioning in the pregnant ewe: effects of undernutrition and exercise
}

\author{
BY B. J. LEURY*, A. R. BIRD†, K. D. CHANDLER AND A. W. BELL $\$$ \\ School of Agriculture, La Trobe University, Bundoora, Victoria 3083, Australia
}

(Received 22 September 1989 - Accepted 18 April 1990)

\begin{abstract}
Maternal whole-body glucose entry rate and uterine and umbilical net uptakes of glucose and oxygen were measured in single-pregnant ewes which were either well-fed throughout, or fed at 0.3-0.4 predicted energy requirement for 7-21 d during late pregnancy. All ewes were studied while standing at rest and then while walking on a treadmill at $0.7 \mathrm{~m} / \mathrm{s}$ on a $10^{\circ}$ slope for $60 \mathrm{~min}$. Underfed ewes suffered significant decreases in live weight and had lower fetal, but not placental, weights at 140-144 d gestation. Undernutrition also caused large decreases in maternal glycaemia and glucose entry rate, which were associated with equally large decreases in uterine and umbilical net uptakes and $\mathrm{O}_{2}$ quotients of glucose, and with a decrease in placental glucose transfer capacity. Exercise caused increases in maternal blood concentration, entry rate and uterine net uptake of glucose, the magnitudes of which were not significantly affected by plane of nutrition. Umbilical glucose uptake and placental glucose transfer capacity increased during exercise in underfed but not fed ewes. The fractional distribution of maternal glucose to the pregnant uterus, and of uterine glucose uptake to the fetus, were unaltered by undernutrition; during exercise, a disproportionately small fraction of the increased maternal glucose supply went to the uterus. The results confirm that the ovine conceptus responds to nutritional reduction in maternal glucose availability in a manner similar to non-uterine maternal tissues. Major reductions in glucose supply appear to override putative glucose-sparing mechanisms which may operate to favour the conceptus in better-nourished animals.
\end{abstract}

Glucose: Pregnancy : Uterus: Fetus: Sheep

It is well-established that the growing sheep conceptus makes substantial demands on the maternal glucose supply, especially in late pregnancy. At this time the gravid uterus may account for about $30-50 \%$ of whole-body glucose utilization in well-fed, monotocous ewes (Hay et al. 1983; Oddy et al. 1985). However, there is conflicting evidence on the degree to which uterine glucose consumption is responsive to changes in maternal supply. On the one hand, the findings of Oddy et al. (1985) appear to support the long-held notion (e.g. Barcroft, 1946) that when maternal glucose production is limited by undernutrition, the unmodified demands of the conceptus take priority over those of maternal tissues. On the other, studies by Hay et al. $(1983,1984 \mathrm{~b})$ strongly suggest that fetal and utero-placental uptake of maternal glucose is attenuated in proportion with the reduction of maternal supply during short-term starvation.

Therefore, in the present study we re-investigated the effects of undernutrition during late pregnancy on the partitioning of maternal glucose between the pregnant uterus and nonuterine maternal tissues and, within the uterus, between fetal and utero-placental tissues. In the same animals we also examined uterine and fetal responses to an acute perturbation of maternal glucose metabolism, achieved by treadmill exercise. Results confirm that the ovine conceptus is indeed responsive to nutritional reduction in maternal glucose supply,

Present addresses: * Rutherglen Research Institute, Department of Agriculture and Rural Affairs, Rutherglen, Victoria 3685, Australia; † Toorak Research Station, Department of Primary Industries, Julia Creek, Queensland 4823, Australia; $\ddagger$ Department of Animal Science, Cornell University, Ithaca, New York 14853-4801, USA.

$\S$ For reprints. 
to a similar degree as non-pregnant maternal tissues. In exercising ewes, uterine net uptake of glucose increased in response to a substantial increase in maternal glucose flux. This was accompanied by a major increase in umbilical net uptake in underfed, but not in well-fed ewes.

\section{MATERIALS AND METHODS}

\section{Animals and management}

Twenty-two single-pregnant, multiparous Merino ewes, weighing $31-45 \mathrm{~kg}$ at surgery, were used. Time of mating was detected by colour marks left on ewes by rams fitted with coloured crayons (Sire-sine; Hortico, Melbourne, Victoria). Ewes were inspected daily and date of conception was taken as the first date of marking followed by subsequent failure to mate. Ewes were brought indoors at $80-100 \mathrm{~d}$ post-coitus (pc), housed in individual metabolism cages and accustomed to experimental surroundings and procedures, including walking on a moving-belt treadmill, for several weeks before the experiment.

Feeding. Ewes were given 800-1200 g lucerne (Medicago sativa) chaff (metabolizable energy (ME) content approximately $9 \mathrm{MJ} / \mathrm{kg}$ ) per d, according to body-weight and stage of pregnancy, until surgery at $115-120 \mathrm{~d}$ pc. After they had re-attained presurgery feed intakes (usually $2-3 \mathrm{~d}$ post-surgery) they were randomly assigned to one of two nutritional treatments: eleven ewes were given $1000-1200 \mathrm{~g}$ lucerne chaff/d (fed group) and the remaining eleven were given $350 \mathrm{~g}$ lucerne chaff/d (underfed group), until they were slaughtered at 140-144 d pc. In both groups the daily ration was given in twelve equal portions at two-hourly intervals, with ad lib. access to water and a mineralized salt block (Cheetham Salt, Geelong, Victoria).

Surgery. Ewes at $115-120 \mathrm{~d} \mathrm{pc}$ were fasted for $24 \mathrm{~h}$ before general anaesthesia was induced by intravenous injection of thiopentone sodium (Pentothal; Abbott Laboratories, Kurnell, Australia) and maintained with a halothane (Fluothane; ICI, Villawood, Australia) - oxygen mixture $(3: 97, \mathrm{v} / \mathrm{v})$ given in closed-circuit through an endotracheal tube. The uterine vein draining the pregnant horn of the uterus and the common umbilical vein were catheterized as described by Meschia et al. (1969) and the fetal abdominal aorta as described by Chandler \& Bell (1981). Catheters were also inserted into the fetal posterior vena cava via a lateral saphenous vein and into the maternal abdominal aorta via a medial saphenous artery. Post-operative care of ewes, including antibiotic treatment, and maintenance of catheter patency were as described previously (Chandler \& Bell, 1981). On the day before an experiment, a catheter was placed in an external jugular vein of each ewe.

\section{Experimental procedure}

Experiments were performed on fed ewes at least $7 \mathrm{~d}$ after surgery, when they were at 123-137 d pc, and on underfed ewes at 10-22 d after surgery, when they had been underfed for $7-21 \mathrm{~d}$, and were at $124-138 \mathrm{~d}$ pc. Where possible, two studies per animal were attempted, with an interval of at least 1 week between studies. Ewes were killed with an overdose of sodium pentobarbitone at $140-144 \mathrm{~d}$ pc to measure weights of the pregnant uterus, fetus and placenta.

On the day of study, experimental infusions were begun at least $45 \mathrm{~min}$ after the ewe had been placed on the stationary treadmill. D- $\left[2{ }^{3} \mathrm{H}\right]$ glucose (nominal specific activity $15 \mathrm{Ci} / \mathrm{mmol}$; A mersham, Bucks), dissolved in sterile isotonic saline ( 9 g sodium chloride $/ 1$ ), was given by primed continuous infusion into a maternal jugular vein (priming dose $80 \mu \mathrm{Ci}$, followed by continuous infusion at $0.8 \mu \mathrm{Ci} / \mathrm{min}$ ). At the same time, infusion of antipyrine $(20-30 \mathrm{mg} / \mathrm{min}$, dissolved in sterile isotonic saline) into the fetal vena cava was commenced, for measurement of umbilical and uterine blood flows (see p. 451). Blood samples were simultaneously drawn from the maternal aorta and uterine vein (each $5 \mathrm{ml}$ ), fetal aorta and 
common umbilical vein (each $1.2 \mathrm{ml}$ ) at about 90,110,130 and $150 \mathrm{~min}$ after infusions commenced, while the ewe stood at rest. Additional maternal and fetal arterial samples were taken at about 100,120 and $140 \mathrm{~min}$.

The ewe then commenced walking $\left(0.7 \mathrm{~m} / \mathrm{s}, 10^{\circ}\right.$ slope $)$ and the previously described sampling routine was repeated after about 40,50 and $60 \mathrm{~min}$ of exercise. Additional maternal and fetal arterial samples were taken after 5, 10, 15, 20 and $30 \mathrm{~min}$ of exercise.

Blood samples for measurement of $\mathrm{O}_{2}$ content were sealed and stored anaerobically in glass syringes on ice before analysis within $1 \mathrm{~h}$ of sampling. Samples for analysis of glucose concentration and specific radioactivity (SRA) and of antipyrine were stored on ice in capped, heparinized syringes before being deproteinized with zinc sulphate-barium hydroxide (Somogyi, 1945); supernatant fractions were stored at $-20^{\circ}$.

\section{Measurements}

Uterine and umbilical blood flows were measured by the transplacental steady-state diffusion technique (Meschia et al. 1967). Blood concentrations of antipyrine were measured by the method of Brodie et al. (1949), as modified by Chandler (1983). Blood haemoglobin $(\mathrm{Hb})$ and oxyhaemoglobin saturation $\left(S_{\mathrm{O}_{2}}\right)$ were measured in an automatic, direct reading photometer (OSM2; Radiometer A/S, Copenhagen, Denmark) calibrated with sheep's blood. Blood $\mathrm{O}_{2}$ content $(\mathrm{ml} / \mathrm{l})$ was calculated as: $\mathrm{Hb}(\mathrm{g} / \mathrm{l}) \times S_{\mathrm{O}_{2}} \times 1 \cdot 34$. Blood glucose was analysed by the glucose oxidase ( $E C 1.1 .1 .34)$ method of Bergmeyer \& Bernt (1974). Glucose SRA was determined after anion-exchange chromatography, freeze-drying to remove ${ }^{3} \mathrm{H}_{2} \mathrm{O}$ and reconstitution in $0.5 \mathrm{ml}$ water; the procedures were essentially those of Hay et al. (1981) as slightly modified by Leury (1987). Samples derived from blood extracts and infusates for a given experiment were counted at the same time in a Packard Tricarb 460C liquid-scintillation system (Packard Instrument Co., IL, USA).

\section{Calculations}

Net fluxes of $\mathrm{O}_{2}$ and glucose from the uterine circulation to the pregnant uterus were calculated as the product of uterine blood flow and maternal arterial-uterine venous concentration difference. Similarly, net fluxes from the placenta to the fetus were calculated as the product of umbilical blood flow and the umbilical venous-arterial concentration difference. Net utero-placental utilization of $\mathrm{O}_{2}$ and glucose were calculated as the difference between the net uterine and net umbilical rates of exchange (Meschia et al. 1980). Placental glucose transfer capacity $(\mathrm{ml} / \mathrm{min})$ was calculated as the quotient of umbilical uptake and maternal arterial-fetal arterial concentration difference of glucose. This term should be distinguished from placental glucose transfer rate (i.e. umbilical uptake). It is equivalent to placental glucose clearance if the potential influence of placental glucose metabolism on net transfer is ignored.

Whole-body glucose entry rate was calculated by dividing the infusion rate of $\left[{ }^{3} \mathrm{H}\right] \mathrm{glucose}$ (disintegrations/min (dpm) per min) by maternal blood glucose SRA after the latter was no longer time-dependent. In resting ewes, preliminary experiments showed that this plateau was achieved after about $60 \mathrm{~min}$. Despite the short duration of exercise, a new plateau SRA was usually discernible after about $30 \mathrm{~min}$. Thus, entry rates calculated by the above steady-state approach were not significantly different from those calculated using the non-steady state equation of de Bodo et al. (1963), as validated for estimation of glucose flux rate in exercising sheep (Brockman, 1984).

\section{Statistics}

Where more than one study was done per animal, the values were averaged before statistical analysis of treatment effects. The significance of the effects of exercise were 
Table 1. Maternal and fetal body-weights $(\mathrm{kg})$ and placental weight $(\mathrm{g}) \dagger$ in well-fed and underfed ewes $\$$

(Values are means with their standard errors; no. of animals in parentheses)

\begin{tabular}{|c|c|c|c|c|c|c|}
\hline & \multirow{2}{*}{$\begin{array}{l}\text { Gestational } \\
\text { age (d) }\end{array}$} & \multicolumn{2}{|c|}{ Fed } & \multicolumn{2}{|c|}{ Underfed } & \multirow{2}{*}{$\begin{array}{l}\text { Effect of } \\
\text { nutrition }\end{array}$} \\
\hline & & Mean & $\mathrm{SE}$ & Mean & SE & \\
\hline Ewe & 120 & $41 \cdot 5$ & $1.9(9)$ & $40 \cdot 9$ & $1 \cdot 0(11)$ & NS \\
\hline Ewe & $140-144$ & $43 \cdot 1$ & $2.8(7)$ & $36 \cdot 5$ & $1 \cdot 2(8)$ & * \\
\hline Fetus & $140-144$ & $3 \cdot 83$ & $0.14(9)$ & $3 \cdot 22$ & $0 \cdot 22(9)$ & * \\
\hline Placenta & $140-144$ & 367 & $23(8)$ & 338 & $19(8)$ & NS \\
\hline
\end{tabular}

NS, not significant

$* P<0.05$.

$\dagger$ Aggregate weight of whole placentomes, dissected from fetal membranes and endometrium.

‡ For details of feeding regimen, see p. 450 .

assessed by the paired $t$ test with $n-1$ degrees of freedom, where $n$ is the number of pairs. The effect of undernutrition on resting absolute values and on exercise-induced changes from resting values were assessed by the unpaired $t$ test. Relations between variables were determined by least-squares linear-regression analysis.

\section{RESULTS}

Numbers of observations shown in the Tables rarely match the number of sheep (eleven) used per treatment, mainly because we were unable to maintain patency of all catheters in all animals on all sampling days, and because more than one study was done on some animals.

\section{Maternal, fetal and placental weights}

Mean live weight increased by about $2 \mathrm{~kg}$ in fed ewes during the period of study, but decreased by about $4 \mathrm{~kg}$ in the underfed group, so that the latter were significantly lighter than the former when slaughtered at $140-144 \mathrm{~d}(P<0.05)$ (Table 1). Mean fetal weight at this time was about $600 \mathrm{~g}(16 \%)$ less in underfed than in fed ewes $(P<0.05)$, but placental weights were not significantly affected by maternal nutrition (Table 1 ).

\section{Uterine and umbilical blood flows and $\mathrm{O}_{2}$ exchanges}

In resting ewes, uterine blood flow tended to be lowered by underfeeding $(P<0 \cdot 1)$, whereas umbilical blood flow was unaffected by plane of nutrition (Table 2). During exercise, uterine blood flow decreased by 18 and $27 \%$ in fed and underfed ewes respectively (both $P<0.01)$, but the absolute decrease $(\mathrm{ml} / \mathrm{min})$ in uterine flow was not affected by nutrition (Table 2). Exercise-induced changes in umbilical blood flow were smaller and less consistent.

Maternal and fetal arterial blood $\mathrm{O}_{2}$ concentrations were unaffected by maternal plane of nutrition (Table 3). Uterine $\mathrm{O}_{2}$ uptake was lower in underfed than in fed ewes $(P<0.05$; Table 3). This was entirely explained by a $60 \%$ reduction in utero-placental $\mathrm{O}_{2}$ consumption $(P<0 \cdot 01)$, since umbilical $\mathrm{O}_{2}$ uptake was unchanged by maternal plane of nutrition (Table 3).

Maternal arterial $\mathrm{O}_{2}$ concentration was significantly increased during exercise in fed $(P<0.001)$ and underfed $(P<0.01)$ ewes, while fetal arterial $\mathrm{O}_{2}$ concentration was decreased by $18 \%(P<0.05)$ and $23 \%(P<0.01)$ in fed and underfed groups respectively (Table 3). Uterine $\mathrm{O}_{2}$ uptake and its partition between the fetus and utero-placental tissues 
Table 2. Effects of undernutrition and exercise on uterine and umbilical blood flows in ewest

(Values are means with their standard errors; no. of studies and no. of sheep respectively in parentheses)

\begin{tabular}{|c|c|c|c|c|c|c|c|c|c|c|}
\hline \multirow{3}{*}{$\begin{array}{l}\text { Blood flow } \\
\text { (ml/min) }\end{array}$} & \multicolumn{4}{|c|}{ Fed } & \multicolumn{4}{|c|}{ Underfed } & \multirow{2}{*}{\multicolumn{2}{|c|}{$\begin{array}{l}\text { Effect of } \\
\text { nutrition }\end{array}$}} \\
\hline & \multicolumn{2}{|c|}{$\mathbf{R}$} & \multicolumn{2}{|c|}{$\Delta \mathrm{E}$} & \multicolumn{2}{|c|}{$\mathbf{R}$} & \multicolumn{2}{|c|}{$\Delta \mathrm{E}$} & & \\
\hline & Mean & $\mathrm{SE}$ & Mean & SE & Mean & $S E$ & Mean & $\mathrm{SE}$ & $\mathbf{R}$ & $\Delta \mathrm{E}$ \\
\hline Uterine & 1506 & 122 & ${ }_{9)} 265^{* *}$ & 57 & 1206 & & $\frac{-329 * *}{10)}$ & 67 & NS & NS \\
\hline Umbilical & 677 & 45 & $9^{-59}$ & 29 & 719 & 65 & $11)^{-32}$ & 54 & NS & NS \\
\hline
\end{tabular}

$\mathrm{R}$, rest; $\Delta \mathrm{E}$, change with exercise; NS, not significant.

$* P<0.05, * * P<0.01$.

+ For details of feeding regimen and exercise, see pp. 450-451.

Table 3. Effects of undernutrition and exercise on maternal and fetal arterial blood concentrations, and on uterine and umbilical exchanges of oxygen in ewes $\dagger$ (Values are means with their standard errors; no. of studies and no. of sheep respectively in parentheses)

\begin{tabular}{|c|c|c|c|c|c|c|c|c|c|c|}
\hline & \multicolumn{4}{|c|}{ Fed } & \multicolumn{4}{|c|}{ Underfed } & \multirow{2}{*}{\multicolumn{2}{|c|}{$\begin{array}{l}\text { Effect of } \\
\text { nutrition }\end{array}$}} \\
\hline & \multicolumn{2}{|c|}{$\mathrm{R}$} & \multicolumn{2}{|l|}{$\Delta \mathrm{E}$} & \multicolumn{2}{|c|}{$\mathbf{R}$} & \multicolumn{2}{|c|}{$\Delta \mathrm{E}$} & & \\
\hline & Mean & SE & Mean & SE & Mean & $\mathrm{SE}$ & Mean & $\mathrm{SE}$ & $\mathrm{R}$ & $\Delta \mathrm{E}$ \\
\hline \multicolumn{11}{|c|}{ Arterial $\mathrm{O}_{2}$ concentration $(\mathrm{ml} / \mathrm{l})$} \\
\hline Maternal & $107 \cdot 0$ & 3.6 & $\begin{array}{l}+25 \cdot 7 * * * \\
(10,9)\end{array}$ & $4 \cdot 9$ & $103 \cdot 3$ & $4 \cdot 4$ & $\begin{array}{l}+20 \cdot 4^{* *} \\
2,9)\end{array}$ & $5 \cdot 2$ & NS & NS \\
\hline Fetal & $77 \cdot 7$ & $5 \cdot 0$ & $(11,9)=$ & $5 \cdot 1$ & $83 \cdot 0$ & $4 \cdot 7$ & $\begin{array}{l}-19 \cdot 4^{* *} \\
10)\end{array}$ & $4 \cdot 6$ & NS & NS \\
\hline \multicolumn{11}{|c|}{$\mathrm{O}_{2}$ consumption $(\mathrm{ml} / \mathrm{min})$} \\
\hline Uterine & $33 \cdot 5$ & $2 \cdot 0$ & $(12,9)^{+4 \cdot 2^{*}}$ & $1 \cdot 3$ & $27 \cdot 1$ & $2 \cdot 2$ & $(, 9)^{+4 \cdot 0}$ & $3 \cdot 6$ & * & NS \\
\hline Umbilical & $20 \cdot 3$ & 0.6 & $\begin{array}{l}+1 \cdot 6 \\
(12,9)\end{array}$ & $1 \cdot 0$ & $20 \cdot 5$ & $1 \cdot 5$ & $\left.{ }^{+3 \cdot 0}, 10\right)^{+3 \cdot 0}$ & $1 \cdot 8$ & NS & NS \\
\hline Uteroplacental & $14 \cdot 8$ & $2 \cdot 3$ & ${ }^{+1.7}$ & $2 \cdot 4$ & 60 & 1.6 & $(2,9)^{+2 \cdot 1}$ & $3 \cdot 0$ & $* *$ & NS \\
\hline
\end{tabular}

$R$, rest; $\triangle \mathrm{E}$, change with exercise; NS, not significant.

${ }^{*} P<0.05, * * P<0.01, * * * P<0.001$.

$\dagger$ For details of feeding regimen and exercise, see pp. $450-451$.

were largely unchanged by exercise, although a small, significant increase in uterine uptake was observed in fed ewes $(P<0 \cdot 05)$ (Table 3$)$.

\section{Glucose metabolism}

Maternal and uterine. Undernutrition caused approximately $50 \%$ reductions in maternal blood concentration $(P<0.001)$, whole-body entry rate $(P<0.001)$ and uterine net uptake $(P<0.01)$ of glucose, and a somewhat smaller $(34 \%)$ decrease in uterine glucose: $\mathrm{O}_{2}$ quotient $(P<0.05)$ (Table 4$)$. Exercise caused increases in maternal blood concentration (fed $P<0.1$, underfed $P<0.001$ ), entry rate (fed $P<0.01$, underfed $P<0.001$ ) and uterine 
B. J. LEURY AND OTHERS

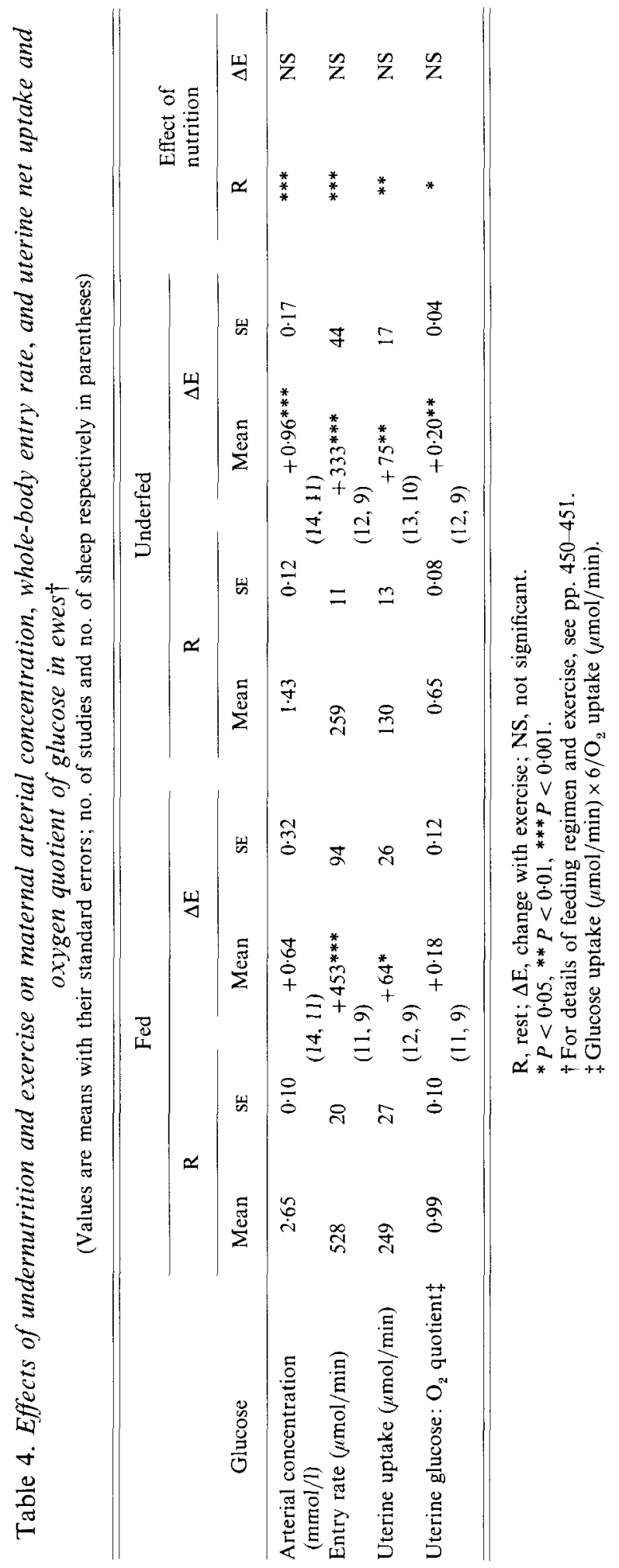



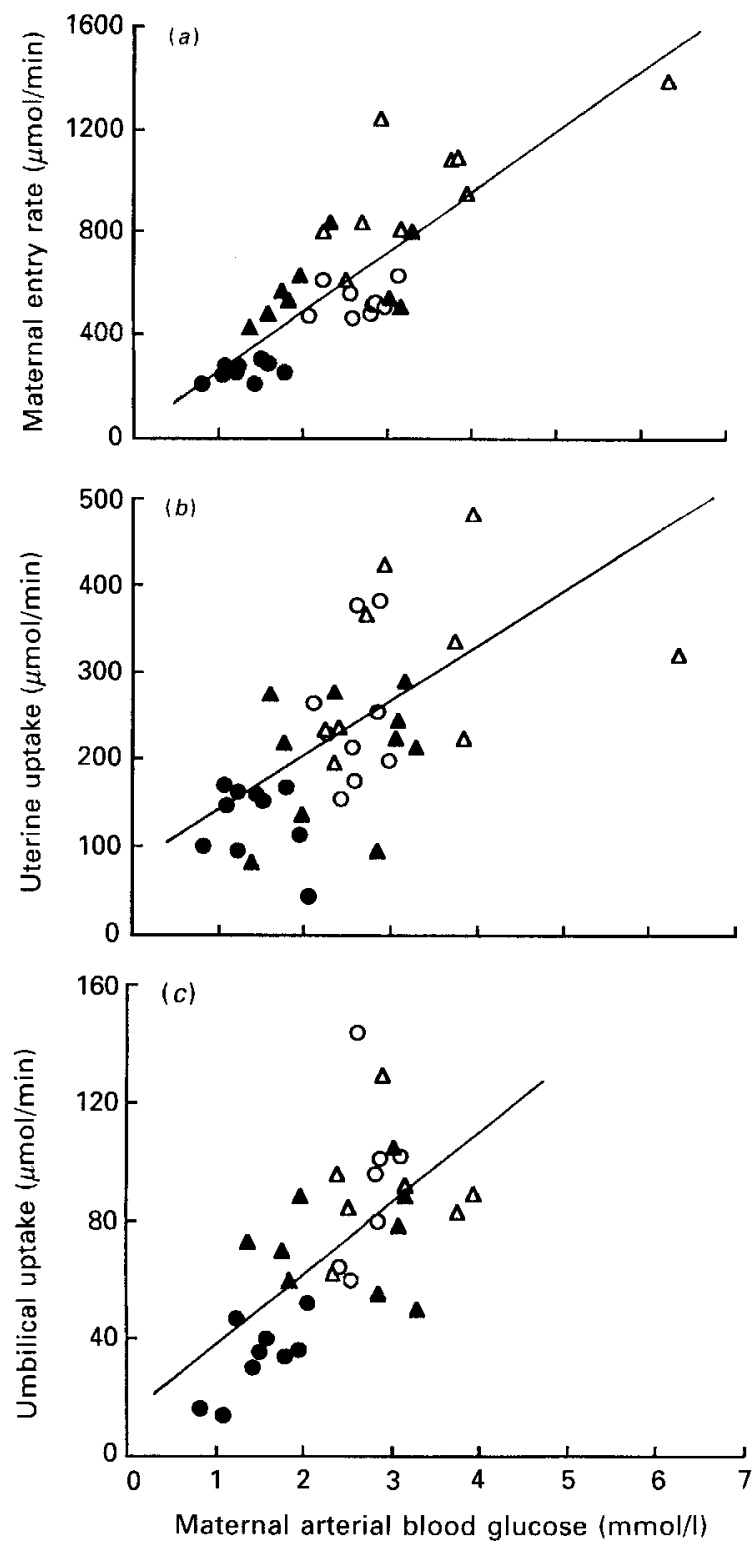

Fig, 1. Relations between maternal blood glucose concentration and $(a)$ maternal glucose entry rate $(y=228 x+32, r 0.83, n 36, P<0.001),(b)$ uterine net glucose uptakc $(y=52 x+83, r 0.54, n 38, P<0.001)$ and (c) umbilical net glucose uptake $(y=25 \cdot 7 x+9 \cdot 4, r 0 \cdot 66, n 32, P<0.001)$ in fed $(0, \triangle)$ and underfed $(\mathbf{O}, \Delta)$ ewes at rest $(O, \boldsymbol{O})$ and during exercise $(\triangle, \Delta)$. For details of feeding regimen and exercise, see pp. $450-451$.

uptake of glucose (fed $P<0 \cdot 05$, underfed $P<0 \cdot 01$ ), none of which was significantly affected by plane of nutrition. Mean increases in uterine glucose: $\mathrm{O}_{2}$ quotient were significant in underfed $(P<0.01)$ but not in fed ewes (Table 4$)$.

When values from all treatments (fed, underfed, rest, exercise) were pooled, both maternal entry rate (Fig. 1(a)) and uterine net uptake of glucose (Fig. 1(b)) were significantly correlated with maternal arterial blood glucose concentration (both $P<0.001)$ 


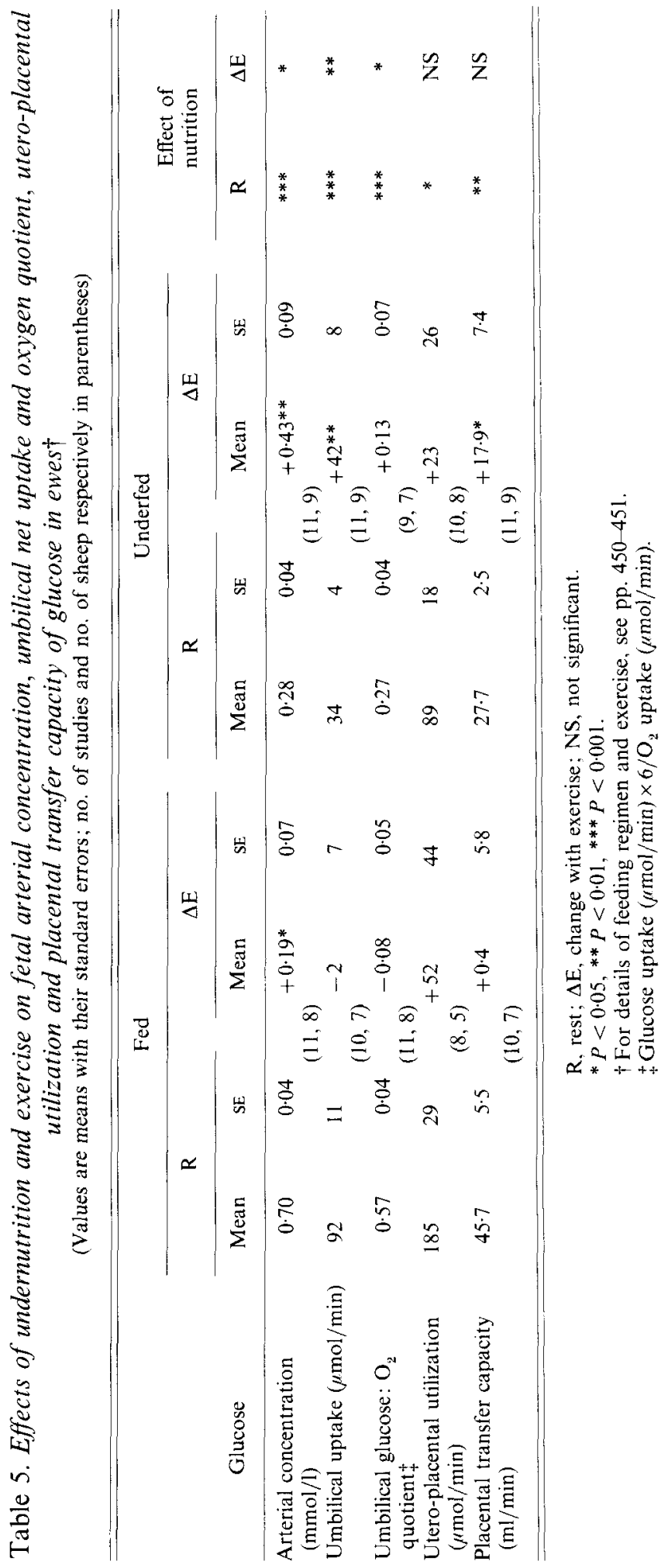



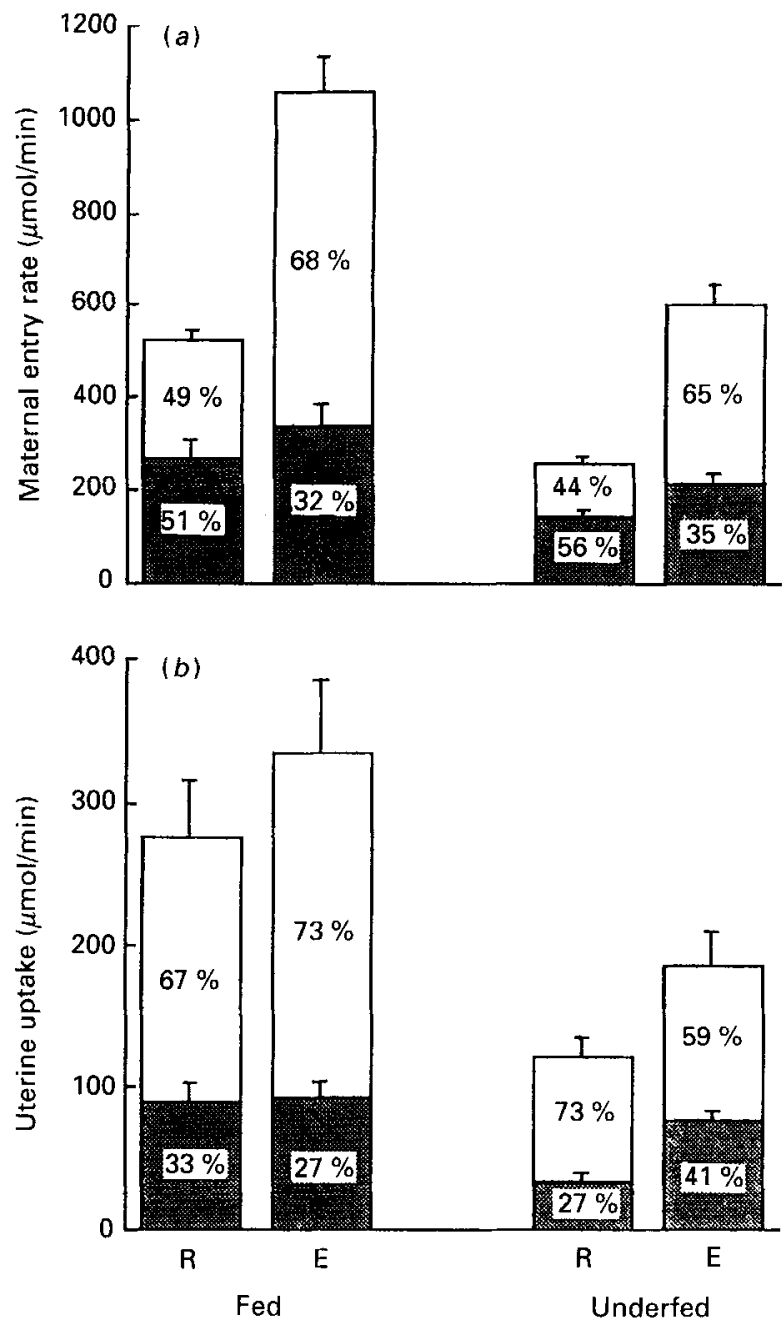

Fig. 2. Partition of ( $a$ ) maternal glucose entry rate between pregnant uterus (圈) and maternal non-uterine tissues $(\square)$, (b) uterine net uptake of glucose between the fetus (图) and uteroplacental tissues ( $\square$ ) in fed and underfed ewes at rest $(R)$ and during exercise (E). Values are means with standard errors represented by vertical bars.

Fetal and uteroplacental. Maternal underfeeding caused greater than $50 \%$ reductions in fetal glycaemia $(P<0 \cdot 001)$, umbilical net glucose uptake $(P<0 \cdot 001)$, umbilical glucose: $\mathrm{O}_{2}$ quotient $(P<0.001)$ and utero-placental glucose utilization $(P<0.05)$, and a $40 \%$ reduction in placental glucose transfer capacity $(P<0.01)$ (Table 5$)$. Exercise resulted in increased fetal blood glucose concentrations (fed $P<0.05$, underfed $P<0.01$ ), which were significantly greater in underfed ewes $(P<0 \cdot 05)$. Umbilical glucose uptake was unaffected by exercise in fed ewes, but increased more than twofold $(P<0-01)$ in underfed ewes (effect of nutrition $P<0.01$ ). Mean increases in utero-placental glucose utilization during exercise were variable and not statistically significant. Placental glucose transport capacity was unchanged in fed ewes but increased in underfed ewes $(P<0.05)$ during exercise (Table 5).

Umbilical net uptake of glucose was significantly correlated with maternal arterial blood glucose concentration when values were pooled across treatments $(P<0.001$; Fig. $1(c))$. 


\section{Glucose partitioning}

Simultaneous measurements of all variables of glucose metabolism were obtained in too few animals within each treatment group for these to be representative of overall treatment effects. Therefore, the partitioning of glucose between uterine and maternal non-uterine tissues is presented separately (Fig. $2(a)$ ) from that within the uterus, between fetal and utero-placental tissues (Fig. 2(b)).

The fraction of maternal glucose entry rate accounted for by the pregnant uterus was not significantly affected by plane of nutrition (Fig. 2(a)), but was reduced by exercise to a similar degree in fed $(P<0.05)$ and underfed ewes $(P<0.01)$, despite significant absolute increases in uterine glucose uptake (Table 3 ). The fractional distribution of uterine glucose uptake between the fetus and utero-placental tissues was not significantly affected by maternal nutrition or exercise (Fig. 2(b)).

\section{DISCUSSION}

\section{Effects of undernutrition}

The severity of undernutrition imposed in the present study $(0.3-0.4$ recommended ME intake) was reflected by substantial loss of maternal live weight and development of hypoglycaemia during the treatment period of approximately 3 weeks. This was accompanied by a significant decline in fetal weight as previously observed in monotocous Merino ewes which were underfed during late pregnancy (Everitt, 1968; Alexander \& Williams, 1971). It is likely that fetal growth retardation was mainly a direct consequence of inadequate maternal nutrient supply, since placental weight was little affected. Additional compromise of fetal nutrient supply through reduction in placental size appears to occur only after more prolonged undernutrition (see Mellor, 1983). Nevertheless, decreased weight-specific functional activity of the placenta is indicated by the decreased placental glucose transfer capacity, together with depressed utero-placental blood flow and $\mathrm{O}_{2}$ and glucose consumption in undernourished ewes (Chandler et al. 1985; present study).

Present values for glucose entry rate in resting, fed ewes, when adjusted for body-weight, were similar to those previously reported for well-fed, monotocous ewes in late pregnancy (Steel \& Leng, $1973 a$; Baird et al. 1983; Wilson et al. 1983). The use of $\left[2-{ }^{3} \mathrm{H}\right]$ glucose as tracer provides a maximal estimate of the rate at which glucose enters the bloodstream, including the recycling of glucose-C through non-hexose intermediates (Judson \& Leng, 1972). This was deemed an acceptable kinetic variable on which to base estimates of glucose partitioning, not least because in the present study values for uterine uptake of glucose were not corrected for the considerable efflux of lactate from the pregnant uterus (Burd et al. 1975; Faichney et al. 1981). The major decrease in glucose entry rate of underfed ewes was quantitatively similar to that observed in late-pregnant ewes which had been either starved for several days or moderately underfed through mid- and late pregnancy (Steel \& Leng, 1973a). Bergman et al. (1970) showed that in starved, pregnant ewes this was almost entirely attributable to a reduced rate of hepatic glucose synthesis. Thus, any increase in the supply of endogenous glucogenic substrates, such as glycerol, falls far short of making up the deficit in dietary glucose precursors, especially propionate (Steel \& Leng, 1973b), despite the substantial mobilization of body tissue reserves (Table 1).

Decreased maternal glucose supply and glycaemia in underfed ewes were associated with a similar relative reduction in uterine net uptake of glucose, such that the fractional distribution of glucose between the pregnant uterus and non-uterine maternal tissues was essentially unchanged. This and the direct relation between maternal arterial concentration and uterine uptake of glucose agree closely with the findings of Hay et al. (1983), who compared well-fed with acutely fasted ewes. In contrast, Oddy et al. (1985) concluded that uterine glucose uptake at $125 \mathrm{~d} \mathrm{pc}$ was little affected by chronic undernutrition which 
increased in severity throughout pregnancy, despite a $50 \%$ reduction in the rate of wholebody irreversible loss of glucose. It is possible, as suggested by these authors, that their chronically undernourished ewes adapted in a manner different to that of the acutely starved ewes of Hay et al. (1983). However, the present underfed ewes were studied, on average, after $14 \mathrm{~d}$ of treatment, which should have allowed time for significant metabolic adaptation. Also, there must be some uncertainty about the estimates of Oddy et al. (1985) for uterine glucose uptake, which depend on assumed values for uterine weight and do not take account of a likely treatment effect on conceptus growth. In particular, the suggestion that uterine glucose uptake accounts for $84 \%$ of glucose irreversible loss rate in underfed ewes more than 3 weeks before term (Oddy et al. 1985) seems untenably high, although it should be borne in mind that glucose irreversible loss rate is less than glucose entry rate (Steel \& Leng, 1973a; Baird et al. 1983), as measured in the present study.

It appears, then, that in starved or severely undernourished late-pregnant ewes, glucose requirements for the conceptus do not necessarily take priority over those of maternal tissues. This need not conflict with the concept of glucose sparing in better-nourished animals, possibly regulated by homeorhetic modulation of insulin sensitivity or responsiveness in non-uterine maternal tissues (Bauman \& Currie, 1980). However, pregnancy-induced insulin resistance appears to be quantitatively less significant in the sheep than in several non-ruminant species (Hay et al. 1988; Petterson et al. 1989). Thus, in underfed ewes the marked decline in maternal glucose availability may have overridden any advantage conferred on the pregnant uterus by its unresponsiveness to insulin relative to non-uterine peripheral tissues (Hay et al. 1984a).

The present study has corroborated previous findings that partitioning of the reduced uterine glucose uptake between fetus and utero-placental tissues is essentially unaltered by starvation or undernutrition (Hay et al. 1983; Chandler et al. 1985), and that over the range of values observed in well-fed and underfed ewes, umbilical net uptake of glucose is linearly related to maternal glycaemia (Crandell et al. 1983; Hay et al. 1984 b). It has also shown, for the first time, that undernutrition reduces glucose transfer capacity in addition to glucose consumption of the placenta. Thus, the reduction in placental transport (umbilical uptake) of glucose in underfed ewes was greater than could be explained by a decreased maternal-fetal blood concentration gradient. This implies a decreased number or affinity, or both, of glucose transporters in placental cell membranes, which are believed to mediate glucose transport by the ovine placenta (Stacey et al. 1978), since the importance of placental perfusion in limiting placental glucose transfer is relatively small (Wilkening et al. 1985).

\section{Effects of exercise}

Exercise caused a dramatic increase in glucose entry rate in fed and underfed ewes, associated with an increase in maternal glycaemia which was consistently large in underfed ewes, but smaller and less consistent in fed animals. Similar increases in glucose entry rate (Judson et al. 1976; Brockman \& Halvorson, 1982; Leury, 1987) and hepatic glucose production (Brockman, 1987) were observed in non-pregnant sheep exercising at comparable levels. These are most likely achieved initially by rapid stimulation of hepatic glycogenolysis via increased adrenergic activity and, possibly, pancreatic secretion of glucagon (Brockman \& Halvorson, 1982), quickly followed by an increased rate of hepatic gluconeogenesis (Judson et al. 1976; Brockman, 1987). The latter would be favoured by the rapid and sustained increases in plasma concentrations of pancreatic glucagon and cortisol and unchanged plasma insulin as previously reported in fed, pregnant ewes during exercise (Bell et al. 1983).

The large exercise-induced increase in glucose entry rate of severely underfed ewes is remarkable in view of their very low resting rate of glucose synthesis (Table 4) and likely 
depletion of hepatic glycogen stores (Ford, 1962). Much of this may have been sustained by increased gluconeogenesis from non-propionate glucose precursors such as lactate and glycerol, as observed in exercising, non-pregnant sheep fasted for only $24 \mathrm{~h}$ (Brockman, 1987).

A smaller fraction of the increased maternal glucose supply was distributed to the uterus during exercise. This is not surprising, given the greatly increased utilization of, and presumably predominant requirements for, glucose in exercising muscle (Bird et al. 1981; Pethick et al. 1987). Nevertheless, absolute increases in uterine uptake accounted for 14 and $23 \%$ of the increment in whole-body glucose entry rate in fed and underfed ewes respectively. These increases were achieved despite 15-30\% decreases in uterine blood flow, and resulted in significant augmentation of umbilical glucose uptake in underfed but not fed ewes, as previously observed (Chandler et al. 1985). Umbilical glucose uptake is little affected by uterine blood flow within the normal physiological range (Wilkening et al. 1985). The failure of fetal glucose uptake to increase in fed ewes was more likely due to fetal capacity for glucose utilization being limited by hypoxic inhibition of fetal insulin secretion, despite the development of moderate fetal hyperglycaemia (Bell et al. 1983).

Maternal exercise not only substantially increased umbilical uptake but also significantly improved the umbilical glucose $: \mathrm{O}_{2}$ quotient in underfed $v$. fed ewes, suggesting substitution of maternal glucose for the direct or indirect catabolism of other fetal substrates, particularly amino acids. Less than half the increase in umbilical uptake was attributable to the increased gradient between maternal and fetal arterial glucose concentrations. Thus, in underfed but not fed ewes, exercise apparently stimulated a rapid and substantial increase in placental glucose transfer capacity. We do not have a ready physiological explanation for this observation. The role of factors other than insulin in the acute regulation of glucose transporter location and activity in mammalian tisues is poorly understood (Simpson \& Cushman, 1986), and glucose transport in the ovine placenta is relatively insensitive to insulin (Rankin et al. 1986).

In conclusion, it is clear that uterine and fetal uptake of maternal glucose is severely restricted by undernutrition in the resting ewe. However, the present study raises the intriguing possibility that as long as the ewe's body reserves can sustain an adequate glucogenic response to exercise, maternal activity may actually improve fetal nutrient supply and utilization in the undernourished state.

This work was supported by a grant from the Wool Research Trust Fund on the recommendation of the Australian Wool Corporation. The authors are grateful to $\mathrm{Dr}$ W. W. Hay Jr for his critical review of this manuscript.

\section{REFERENCES}

Alexander, G. \& Williams, D. (1971). Heat stress and development of the conceptus in domestic sheep. Journal of Agricultural Science, Cambridge 76, 53-72.

Baird, G. D., van der Walt, J. G. \& Bergman, E. N. (1983). Whole-body metabolism of glucose and lactate in productive sheep and cows. British Journal of Nutrition 50, 249-265.

Barcroft, J. (1946). Researches on Prenatal Life. Oxford: Blackwell.

Bauman, D. E. \& Currie, W. B. (1980). Partitioning of nutrients during pregnancy and lactation: a review of mechanisms involving homeostasis and homeorhesis. Journal of Dairy Science 63, 1514-1529.

Bell, A. W., Bassett, J. M., Chandler, K. D. \& Boston, R. C. (1983). Fetal and maternal endocrine responses to exercise in the pregnant ewe. Joumal of Developmental Physiology 5, 129.141.

Bergman, E. N., Katz, M. L. \& Kaufman, C. F. (1970). Quantitative aspects of hepatic and portal glucose metabolism and turnover in sheep. American Journal of Physiology 219, 785-793.

Bergmeyer, H. U. \& Bernt, E. (1974). D-Glucose. Determination with glucose oxidase and peroxidase. In Methods of Enzymatic Analysis, pp. 1205-1215 [H. U. Bergmeyer, editor]. Weinheim: Verlag Chemie.

Bird, A. R., Chandler, K. D. \& Bell, A. W. (1981). Effects of exercise and plane of nutrition on nutrient utitization by the hind limb of the sheep. Australian Journal of Biological Sciences 34, 541-550. 
Brockman, R. P. (1984). Validation of an equation for calculation of glucose appearance during nonsteady state in sheep. Canadian Journal of Physiology and Pharmacology 62, 341-344.

Brockman, R. P. (1987). Effect of exercise on net hepatic uptake of lactate, pyruvate, alanine, and glycerol in sheep. Canadian Journal of Physiology and Pharmacology 65, 2065-2070.

Brockman, R. P. \& Halvorson, R. (1982). Glucose, glucagon, and insulin during adrenergic blockade in exercising sheep. Journal of Applied Physiology 52, 315-319.

Brodie, B. B., Axelrod, J., Soberman, R. \& Levy, B. B. (1949). The estimation of antipyrene in biological materials. Journal of Biological Chemistry 197, 25-31.

Burd, L. T., Jones, M. D., Simmons, M. A., Makowski, E. L., Meschia, G. \& Battaglia, F. C. (1975). Placental production and fetal utilization of lactate and pyruvate. Nature 254, 710-711.

Chandler, K. D. (1983). Fetal and maternal responses to exercise in the pregnant ewe. M Agr Sc Thesis, La Trobe University.

Chandler, K. D. \& Bell, A. W. (1981). Effects of maternal exercise on fetal and maternal respiration and nutrient metabolism in the pregnant ewe. Journal of Developmental Physiology 3, 161-176.

Chandler, K. D., Leury, B. J., Bird, A. R. \& Bell, A. W. (1985). Effects of undernutrition and exercise during late pregnancy on uterine, fetal and uteroplacental metabolism in the ewe. British Journal of Nutrition 53, 625-635.

Crandell, S. S., Palma, P. A. \& Morriss, F. H. Jr (1983). Umbilical glucose and lactate extractions during maternal hyperglycemia in sheep. American Journal of Physiology 244, R882-R887.

de Bodo, R. C., Steele, R., Altszuler, N., Dunn, A. \& Bishop, J. S. (1963). On the hormonal regulation of carbohydrate metabolism: studies with ${ }^{14} \mathrm{C}$ glucose. Recent Progress in Hormone Research 19, $445-482$.

Everitt, G. C. (1968). Prenatal development in uniparous animals, with particular reference to the influence of maternal nutrition in sheep. In Growth and Development of Mammals, pp. 131-157 [G. A. Lodge and G. E. Lamming, editors]. London: Butterworths.

Faichney, G. J., Barker, P. J., Setchell, B. P. \& Lindsay, D. B. (1981). The utilization of lactic acid by sheep in late pregnancy. Quarterly Journat of Experimental Physiology 66, 195-201.

Ford, E. J. H. (1962). The effect of dietary restriction on some liver constituents of sheep during late pregnancy and early lactation. Journal of Agricultural Science, Cambridge 59, 67-75.

Hay, W. W. Jr, Lin, C.-C. \& Meznarich, H. K. (1988). Effect of high levels of insulin on glucose utilization and glucose production in pregnant and nonpregnant sheep. Proceedings of the Society for Experimental Biology and Medicine 189, 275-284.

Hay, W. W. Jr, Sparks, J. W., Gilbert, M., Battaglia, F. C. \& Meschia, G. (1984a). Effect of insulin on glucose uptake by the maternal hindlimb and uterus, and by the fetus in conscious pregnant sheep. Journal of Endocrinology 100, 119-124.

Hay, W. W. Jr, Sparks, J. W., Quissell, B. J., Battaglia, F. C. \& Meschia, G. (1981). Simultaneous measurements of umbilical uptake, fetal utilization rate, and fetal turnover rate of glucose. American Journal of Physiology 240, E662-E668.

Hay, W. W. Jr, Sparks, J. W., Wilkening, R. B., Battaglia, F. C. \& Meschia, G. (1983). Partition of maternal glucose production between conceptus and maternal tissues in sheep. American Journal of Physiology 245 , E347-E350.

Hay, W. W. Jr, Sparks, J. W., Wilkening, R. B., Battaglia, F. C. \& Meschia, G. (1984 b). Fetal glucose uptake and utilization as functions of maternal glucose concentration. American Journal of Physiology 246, E237-E242.

Judson, G. J., Filsell, O. H. \& Jarrett, I. G. (1976). Glucose and acetate metabolism in sheep at rest and during exercise. Australian Journal of Biological Sciences 29, 215-222.

Judson, G. J. \& Leng, R. A. (1972). Estimation of the total entry rate and resynthesis of glucose in sheep using glucoses uniformly labelled with ${ }^{14} \mathrm{C}$ and variously labelled with ${ }^{3} \mathrm{H}$. Australian Journal of Biological Sciences 25, 1313-1332.

Leury, B. J. (1987). Effects of undernutrition and exercise on glucose metabolism in the pregnant ewe. PhD Thesis, La Trobe University.

Mellor, D. J. (1983). Nutritional and placental determinants of foetal growth rate in sheep and consequences for the newborn lamb. British Veterinary Journal 139, 307-324.

Meschia, G., Battaglia, F. C., Hay, W. W. \& Sparks, J. W. (1980). Utilization of substrates by the ovine placenta in vivo. Federation Proceedings 39, 245-249.

Meschia, G., Cotter, J. R., Makowski, E. L. \& Barron, D. H. (1967). Simultaneous measurement of uterine and umbilical blood flows and oxygen uptakes. Quarterly Journal of Experimental Physiology 52, 1-18.

Meschia, G., Makowski, E. L. \& Battaglia, F. C. (1969). The use of indwelling catheters in uterine and umbilical veins of sheep for a description of fetal acid-base balance and oxygenation. Yale Journal of Biology and Medicine 42, 154-165.

Oddy, V. H., Gooden, J. M., Hough, G. M., Teleni, E. \& Annison, E. F. (I985). Partitioning of nutrients in Merino ewes. II. Glucose utilization by skeletal muscle, the pregnant uterus and the lactating mammary gland in relation to whole body giucosc utilization. Australian Journal of Biological Sciences 38, 95-108.

Pethick, D. W., Harman, N. \& Chong, J. K. (1987). Non-esterified long-chain fatty acid metabolism in fed sheep at rest and during exercise. Australian Journal of Biological Sciences 40, 221-234.

Petterson, J. A., Dunshea, F. R. \& Bell, A. W. (1989). Effects of insulin dose and pregnancy on glucose metabolism in euglycemic sheep. Journal of Animal Science 67, Suppl. 1, 201. 
Rankin, J. H. G., Jodarski, G. \& Shanahan, M. R. (1986). Maternal insulin and placental 3-O-methyl glucose transport. Journal of Developmental Physiology 8, 247-253.

Simpson, I. A. \& Cushman, S. W. (1986). Hormonal regulation of mammalian glucose transport. Annual Reviews of Biochemistry 55, 1059-1089.

Somogyi, M. (1945). A new reagent for the estimation of sugars. Journal of Biological Chemistry 160, 61-68.

Stacey, T. E., Weedon, A. P., Haworth, C., Ward, R. H. T. \& Boyd, R. D. H. (1978). Fetomaternal transfer of glucose analogues by sheep placenta. American Journal of Physiology 234, E32-E37.

Steel, J. W. \& Leng, R. A. (1973a). Effects of plane of nutrition and pregnancy on gluconeogenesis in sheep. 1. The kinetics of glucose metabolism. British Journal of Nutrition 30, 451-473.

Steel, J. W. \& Leng, R. A. (1973 b). Effects of plane of nutrition and pregnancy on gluconeogenesis in sheep. 2. Synthesis of glucose from ruminal propionate. British Journal of Nutrition 30, 475-489.

Wilkening, R. B., Battaglia, F. C. \& Meschia, G. (1985). The relationship of umbilical glucose uptake to uterine blood flow. Journal of Developmental Physiology 7, 313-319.

Wilson, S., MacRae, J. C. \& Buttery, P. J. (1983). Glucose production and utilization in non-pregnant, pregnant and lactating ewes. British Journal of Nutrition 50, 303-316. 